\title{
Evaluating the performance of the OC5 algorithm of IFREMER for the highly turbid waters of Río de la Plata
}

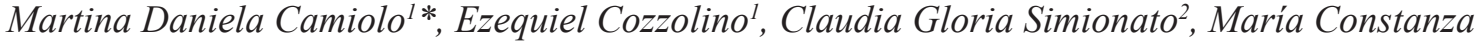 \\ Hozbor ${ }^{3}$, Carlos Ángel Lasta
}

\begin{abstract}
${ }^{1}$ Subprograma de Sensoramiento Remoto, Instituto Nacional de Investigación y Desarrollo Pesquero (INIDEP). Paseo Victoria Ocampo $\mathrm{N}^{\circ}$ 1, Escollera Norte, B7602HSA Mar del Plata, Provincia de Buenos Aires, República Argentina.

${ }^{2}$ Centro de Investigaciones del Mar y la Atmósfera (CIMA/CONICET-UBA); Instituto Franco-Argentino para el Estudio del Clima y sus Impactos (UMI IFAECI/CNRS-CONICET-UBA) and Departamento de Ciencias de la Atmósfera y los Océanos, FCEN, Universidad de Buenos Aires, Argentina. Intendente Güiraldes 2160 - Ciudad Universitaria - Pabellón II - 2do. Piso (C1428EGA) Buenos Aires - Argentina. ${ }^{3}$ Laboratorio de Biología Molecular y Microbiología, Instituto Nacional de Investigación y Desarrollo Pesquero (INIDEP). Paseo Victoria Ocampo Nº1, Escollera Norte, B7602HSA Mar del Plata, Provincia de Buenos Aires, República Argentina.

${ }^{4}$ Dirección de Informaciones, Operaciones y Tecnología, Instituto Nacional de Investigación y Desarrollo Pesquero (INIDEP). Paseo Victoria Ocampo No1, Escollera Norte, B7602HSA Mar del Plata, Provincia de Buenos Aires, República Argentina.
\end{abstract}

*Corresponding author: dcamiolo@inidep.edu.ar

\section{Abstract}

Remote sensing provides a global vision of the oceans; validation is, however, an essential previous step. IFREMER developed the empirical algorithm OC5 for highly turbid (or type 2) waters and it performed well for the northwestern European shelf. The aim of this study was to evaluate the performance of this algorithm for the Río de la Plata estuary, utilizing in situ observations of chlorophyll-a and suspended matter. Our results show a low point-to-point correlation between in situ and remote observations for both variables. In addition, the root mean square log error (RMSE) exceeded 35\% for both variables, indicating a poor performance of the OC5 algorithm. This might be related to the empirical nature of the algorithm, to the amount and distribution of the data used for the analysis, to the species that compose the phytoplankton of the region, to the presence of other optically active substances in the water, and to errors in the atmospheric corrections and/or to the spatial variability of the analyzed variables. In conclusion, our results confirm the need to develop regional algorithms which take into account the particular physical and biological characteristics of the area under study.

Descriptors: Validation, Oc5 Algorithm, Suspended particulate matter, Chlorophyll-a, Río De La Plata.

\section{Resumo}

O sensoriamento remoto fornece uma visão global dos oceanos, embora seja necessária uma validação prévia. O IFREMER desenvolveu o algoritmo empírico OC5 para águas altamente turvas (tipo 2), que mostrou um bom desempenho para essas regiões. Neste trabalho, é analisado o desempenho desse algoritmo no estuário do Rio da Prata, utilizando observações in-situ de clorofila-a e partículas em suspensão. Três métodos diferentes de exclusão foram utilizados para combinar observações insitu e remotas. Os resultados mostram uma baixa correlação entre os dois tipos de observações no estuário para ambas as variáveis. Além disso, a Raiz do Erro Quadrático Médio foi superior a 35\% para as duas variáveis, indicando uma ineficiência do OC5 para os dados capturados pelo MODIS. Esse fraco desempenho pode estar relacionado à natureza empírica do algoritmo, à quantidade e distribuição dos dados utilizados para a análise, às espécies que compõem o fitoplâncton da região, à presença de outras substâncias oticamente ativas na água e aos erros nas correções atmosféricas e/ou na variabilidade espacial das variáveis analisadas. Estes resultados confirmam a necessidade de desenvolver algoritmos regionais considerando as características físicas e biológicas da área em estudo.

Descritores: Validação, Algoritmo Oc5, Material particulado em suspensão, Clorofila-a, Rio da Plata. 


\section{INTRODUCTION}

Estuarine regions play a critical role in the functioning of the planet and undergo enormous pressures due to the increasing number of human activities developed there (OLSEN et al., 2007). The hydrodynamic and biogeochemical processes in estuaries, particularly those related to the concentration of suspended organic and inorganic materials, are complex and driven by the multiple interactions between the morphology, the freshwater discharge, the seawater intrusion and the tides, which determine the circulation patterns and the distribution of properties (LÓPEZ LABORDE; NAGY, 1999). The concentration of suspended materials determines the phytoplankton growth, even if oxygen and nutrients are available in the watershed (PIZARRO; ORLANDO, 1984). Therefore, the knowledge of the concentration of those materials and their spatial and temporal variability are critical to any biological study of estuaries and, particularly, to those in the Rio de la Plata (RDP).

The RDP, located on the eastern coast of Southern South America at $35^{\circ} \mathrm{S}$, drains the second largest river basin of the sub-continent and spans an area covering northern Argentina, Bolivia, Brazil, Paraguay and Uruguay with an area of $3.1 \times 10^{6} \mathrm{~km}^{2}$ (DEPETRIS; GRIFFIN, 1968) and gives rise to one of the largest estuaries of the planet. The amount of sediment carried by its waters has been estimated at more than 160 million tons per year (SIMIONATO et al., 2011b), representing more than $1 \%$ of the overall contribution by rivers to the ocean. Consequently, it constitutes a highly turbid coastal system, with extreme concentrations more than $400 \mathrm{~g} \mathrm{~m}^{-3}$ (FRAMIÑAN; BROWN, 1996).

The RDP is of great ecological, economic and social importance for the countries on its shores (Argentina and Uruguay). It has important artisanal fisheries (LASTA et al., 2001; PUIG et al., 2010); it is a spawning and nursery area for many coastal species (MACCHI; CHRISTIANSEN, 1996; MACHI; ACHA, 1998; JAUREGUIZAR et al., 2008), some of them commercially exploited (LASTA et al., 2001; CAROZZA et al., 2004); and contains one of the most important wetlands in the region, in Bahía Samborombón (BS) (MIANZÁN et al., 2001). The life cycles of the species that inhabit this system are intimately related to its turbidity and concentration of sediments (JAUREGUIZAR et al., 2003, DOGLIOTTI et al., 2011). This association is not yet fully understood, but might be connected with breeding benefits due to an increase in prey abundance (ACHA et al., 2003), due in part to the retentive properties of the system (SIMIONATO et al., 2008; ACHA et al., 2012) and/or to protection from avian predation (JAUREGUIZAR et al., 2003).

Remote sensing provides a comprehensive and synoptic view of the oceans (WILSON et al., 2008). However, for highly turbid (type 2) waters (MOREL; PRIEUR, 1977) such as those of the estuarine region of RDP (FRAMIÑAN; BROWN, 1996), the production of images of turbidity and sediment concentrations based on satellite observations of ocean color constitutes a challenge because there the conventional algorithms used in clear water (type 1) tend to fail (DOGLIOTTI et al., 2011). Based on a set of in situ observations collected in the English Channel and the Bay of Biscay (BB), the Institut Français de Recherche pour l'Explotación de la MER (IFREMER) developed an empirical algorithm, the so-called OC5, for type 2 waters. This algorithm firstly provides the concentration of chlorophyll-a (Chlo-a) (GOHIN et al., 2002). Then, through the implementation of a semi-analytical model, it also gives the concentration of suspended particulate matter (SPM). This parameter is retrieved from the radiance at $555 \mathrm{~nm}$ for concentrations lower than $4 \mathrm{~g} \mathrm{~m}^{-3}$, and from the radiance at $670 \mathrm{~nm}$ for concentrations greater than that value (GOHIN et al., 2005; GOHIN, 2011). OC5 has proven to be efficient with more than 10 years of SeaWIFS (Sea-Viewing Wide Field-of-View Sensor), MODIS (Moderate Resolution Imaging Spectroradiometer) and MERIS (MEdium Resolution Imaging Spectrometer) data for the northwestern European shelf, including the turbid coastal waters of the United Kingdom (SYKES; BARCIELA, 2012). However, the suitability of this algorithm in regions such as the RDP estuary, where suspended sediment concentrations are much higher than in European waters, is not evident. This uncertainty in data retrieved from satellite observations, raises the need to locally validate the algorithm prior to its application (MCCLAIN et al., 2002; BASTIDAS; RODRÍGUEZ-RUBIO, 2006). Thus, the aim of this study is to validate the OC5 algorithm developed by IFREMER for the RDP, with in situ observations gathered in that estuary applying the method of match-ups. We use direct observations of Chlo-a and SPM collected during different research cruises to the RDP. In situ and satellite data are paired applying three different methods. To characterize the relationship between remote and in situ observations we determine the root mean square log error (RMSE) and the Pearson Coefficient of Correlation (PCC). Finally, results are analyzed and discussed. 


\section{MATERIAL AND METHODS}

\section{StUdy AREA}

The RDP estuarine system is one of the most important on the continent (GUERRERO et al., 1997). It is located at approximately $35^{\circ} \mathrm{S}$, on the eastern coast of southern South America, and is one of the frontiers between Argentina and Uruguay (BOSCHI, 1988). It drains an average of about 22,000 $\mathrm{m}^{3} \mathrm{~s}^{-1}$ (URIEN, 1967; CARP, 1989), although extreme values as low as $8,000 \mathrm{~m}^{3} \mathrm{~s}^{-1}$ and as large as $80,000 \mathrm{~m}^{3} \mathrm{~s}^{-1}$ have been observed in association with the cycles of El NiñoSouthern Oscillation (ROBERTSON; MECHOSO, 1998).

The runoff into the estuary mostly comes from the Paraná River and, to a lesser extent, from the Uruguay River. However, the discharge of sediments into the estuary mostly depends on one of the tributaries of the Paraná River, the Bermejo River (INA, 2010), which contributes $75 \%$ of the solid discharge of the Paraná. These sediments are $75 \%$ composed of fine sediments (clays and, especially, silts) and 25\% of sand (SIMIONATO et al., 2011a).

Two of the major harbors of the region (Buenos Aires, Argentina and Montevideo, Uruguay) are located on the RDP shores. The estuary is the main source of fresh water for the millions of inhabitants of the region, for whom it is also an important recreational area (DADÓN; MATTEUCCI, 2006). The RDP is also the nursery area of the white mouth croaker (Micropogonias furnieri) (JAUREGUIZAR et al., 2003, 2008), the species that represents the main coastal fishery of Argentina and Uruguay (ACHA et al., 1999; CAROZZA et al., 2004; JAUREGUIZAR et al., 2008). This estuary is characterized by great variability (SIMIONATO et al., 2004, 2005a; b, 2006, 2007, MECCIA et al., 2009; 2013, LUZ CLARA et al., 2014) mainly due to the high variability of the winds that blow over the region (SIMIONATO et al., 2005b) (Figure 1).

DATA

We used daily normalized reflectances captured by the MODIS-aqua sensor, with a spatial resolution of $1.1 \mathrm{~km}$. MODIS reflectance products Level-2 were downloaded by IFREMER in quasi real-time from the website OceanColor/GSFC (Goddard Space Flight Centre, http:// modis.gsfc.nasa.gov), and then processed with the OC5 algorithm (GOHIN et al., 2005; GOHIN, 2011). The particular images for the RDP region processed for Chlo-a and SPM used in this study were downloaded from the web site http://www.ifremer.fr/nausicaa2/rioplata.

For the validation of the above-mentioned images we used in situ observations of Chlo-a and SPM. The Chlo-a data come from surface water samples collected at the 151

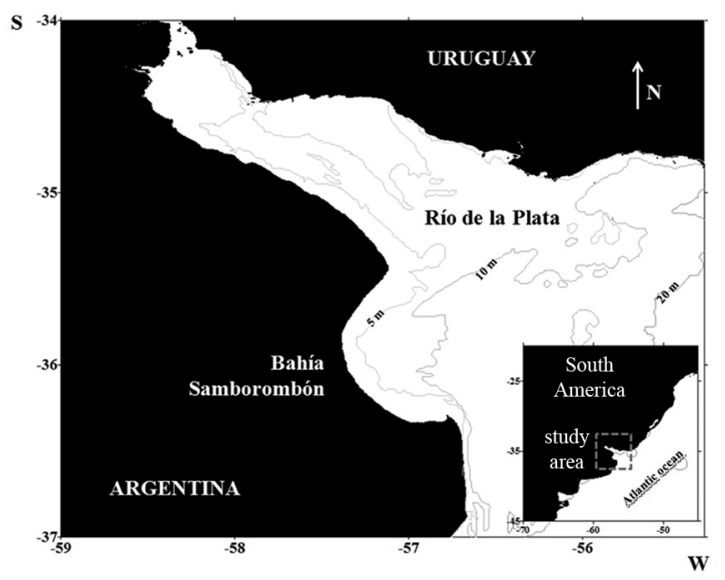

Figure 1. Study area and geographical references.

stations selected during the FREPLATA-FFEM Experiment (Environmental Protection of the Río de la Plata and its Maritime Front/French Fund for the Global Environment) in the period 2009-2010, whose positions are shown in Figure 2A. Samples were processed at the Servicio de Hidrografia Naval Argentina (SIMIONATO et al., 2011a). The phytoplankton was harvested by filtering it through glass paper filters (Whatman GF/C $0.45 \mu \mathrm{m}$ ). The removal of Chlo-a was made in the absence of light, by using $10 \mathrm{ml}$ of acetone at $90 \%$. The suspension was transferred to a centrifuge tube and then centrifuged at $3500 \mathrm{rpm}$ for five minutes. The extract was poured directly into small tubes for the determination of fluorescence on the fluorometer. From the absorbance (A) obtained, the calculations for determining the concentration of Chlo-a were performed by applying Jeffrey and Humphrey's equation (JEFFREY; HUMPHREY, 1975):

src $=$ Chlo $-\left(\mathrm{mgm}^{-3}\right)=v X\left(11,85 D_{663-665}-1,54 D_{647}-0,08 D_{630}\right) / V$

where $v$ is the volume (in $\mathrm{ml}$ ) of acetone extract, and $V$ is the filtered volume (in 1).

In situ SPM data come from the 35 surface water samples whose positions are shown in Figure 3A and all of which were collected during the FREPLATAFFEM Experiment. The determination of SPM was also made at the Servicio de Hidrografía Naval Argentina (SIMIONATO et al., 2011a). In addition, we used 64 samples collected during the cruises to BS made between 2010 and 2012 and whose positions are shown in Figure $3 \mathrm{~A}$. In this case, the determination of SPM was made in the Microbiology Laboratory of the Instituto Nacional de Investigación y Desarrollo Pesquero (INIDEP). Samples were analyzed by the gravimetric method (AMERICAN PUBLIC HEALTH ASSOCIATION, 1999). Glass fiber filters (APFF04700, Millipore) which had been previously 

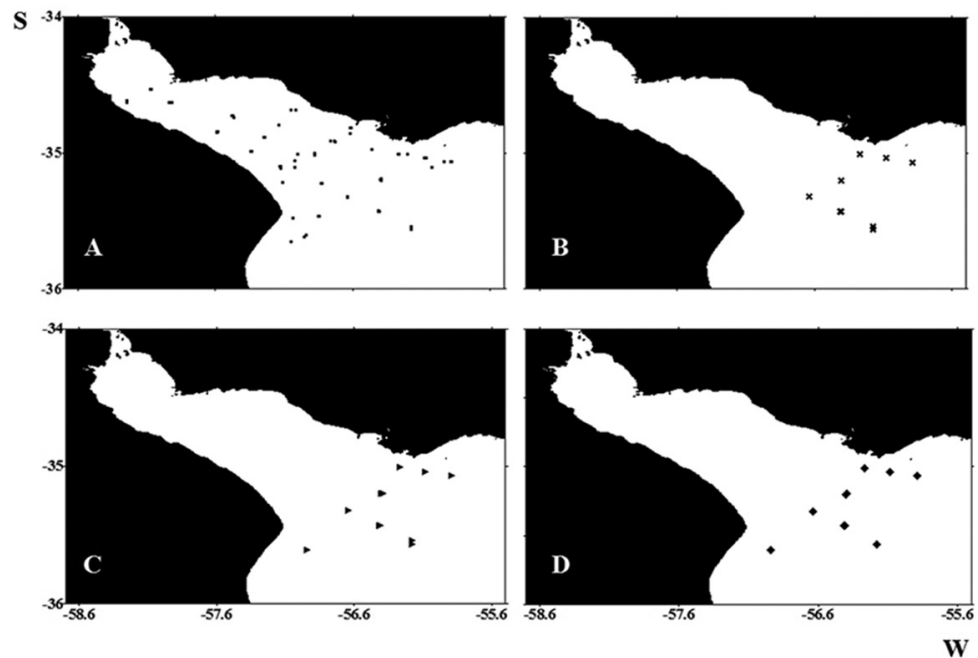

Figure 2. Sites where were chlorophyll-a samples were collected during the FREPLATA-FFEM Experiment (A). Pairs of satellite and field data obtained using the matching methods M1 (B), M2 (C) and M3 (D)

burned $\left(550{ }^{\circ} \mathrm{C}, 30\right.$ minutes $)$ were used. After filtering the water samples, the filters were dried at $100{ }^{\circ} \mathrm{C}$ for 24 hours. SPM concentration was determined by the formula:

\section{SPM $\left(g^{-3}\right)=[$ filter weight dry sediment $(g)-$ filter weight $(\mathrm{g})] \mathrm{X} 10^{6} /$ filtered volume $(\mathrm{l})$}

To assess the correlation between in situ observations and remote sensed data we applied the methodology suggested by BAILEY and WERDELL (2006). For this, $3 \times 3$ pixel boxes with the in situ observation in the center were used; this represents a relatively small region, thus limiting the errors due to spatial variability and navigation (PATT, 2002). We used the average of the values in the box, which implies that we are assuming that the variable in it is almost homogeneous. To determine the homogeneity of the geophysical variables in the chosen box, the coefficient of variation (CV) was used. This is defined as the ratio between the standard deviation and the average of the observations in the pixels included in the box. In order to avoid using data of areas with a high spatial variability (such as regions surrounding clouds) boxes with $\mathrm{CV}$ of more than 0.2 were excluded from the analysis (MCCLAIN et al., 2002). Two different methods of exclusion were defined. Method 1 (M1) corresponds to a $\mathrm{CV}>0.2$ (BAILEY; WERDELL, 2006), whereas method 2 (M2) corresponds to a $\mathrm{CV}>0.4$. We also used a third method (M3) consisting of the determination of the nearest neighbor, in which the field observation is compared to the nearest pixel (QUISPE et al., 2010). To provide an objective
A
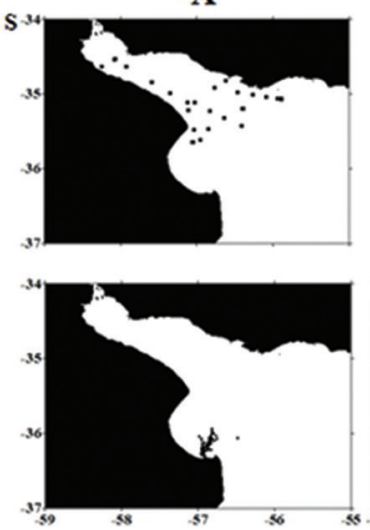

C
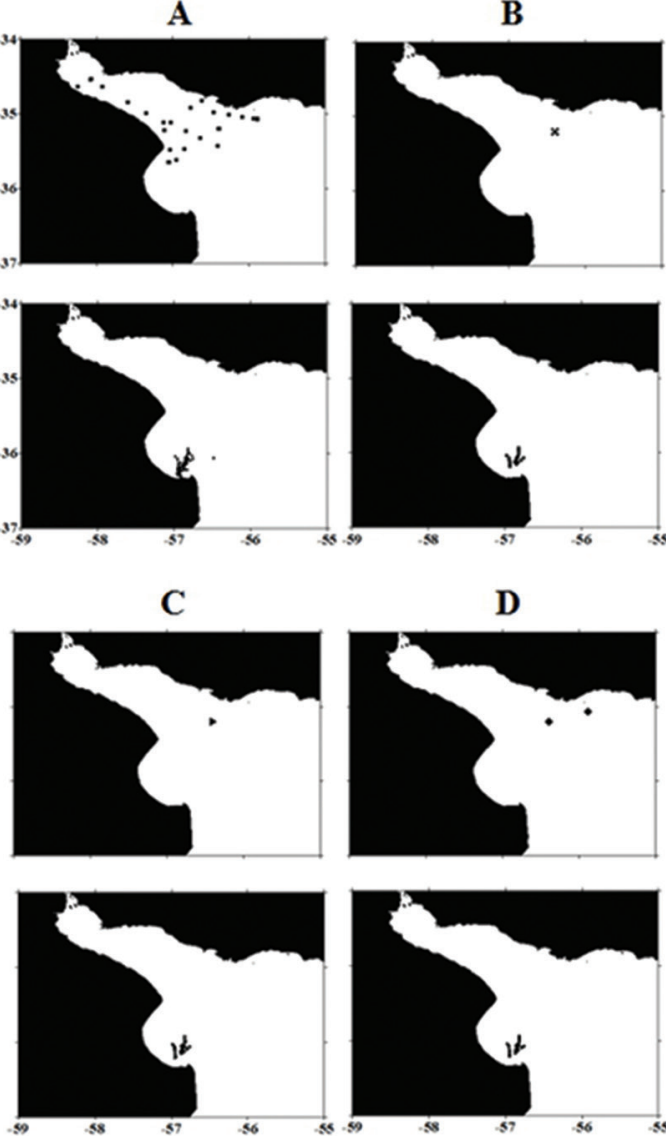

D
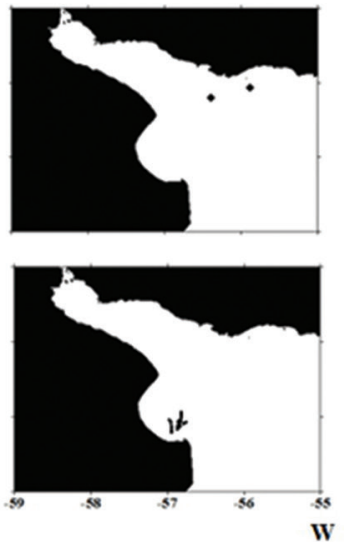

Figure 3. Sites where samples were suspended particulate matter were gathered during the FREPLATA-FFEM Experiment (upper panel) and during the BS cruises (lower panel) (A). Pairs of satellite and field data obtained using the matching methods M1 (B), M2 (C) and M3 (D). 
estimation of the degree of fit between the in situ and satellite observations two different statistics were used: the RMSE (BASTIDAS; RODRÍGUEZ-RUBIO, 2006) and the PCC. Those statistics are defined as:

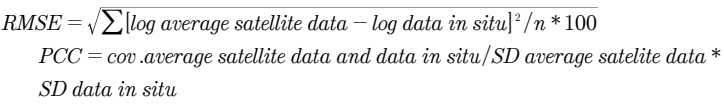

where cov. represents the covariance and SD, the standard deviation.

Prior to the comparison, the field and satellite data were transformed to their base 10 logarithm; this improves the distribution of errors (QUISPE et al., 2010) because the bio-optical data have lognormal distribution (CAMPBELL, 1995). Finally, scatterplots were drawn and the quadratic coefficients of determination or squared correlation coefficients $\left(\mathrm{R}^{2}\right)$ were calculated.

\section{RESULTS}

Table 1 shows the number of data pairs obtained by applying the three different methods of exclusion. The percentage of matching pairs for Chlo-a was low, resulting in $6.6 \%, 7.3 \%$ and $8.61 \%$ of the total, by applying the M1, M2 and M3 methods, respectively. For SPM percentages were higher, resulting in $20 \%, 26 \%$ and $29 \%$, respectively. Figures 2 and 3 show the spatial distribution of matching pairs for each of the three methods, for Chlo-a (Figure 2) and SPM using data from the FREPLATA-FFEM Experiment and the BS cruises (Figure 3). It is evident from the figures that the highest percentages of matches found for SPM are associated with the greater number of samples available for the exterior region of the RDP. Figure 4 shows scatter plots of the matching pairs obtained by methods M1, M2 and M3 and regression lines for Chlo-a (left panel) and SPM (right panel). The equation of the line and the $\mathrm{R}^{2}$ coefficient are also shown. The Chlo-a slopes resulted relatively small and negative $(-0.08$ and -0.03 , respectively) when the M1 and M2 methods were used. When method M3 was applied, the slope was relatively larger and positive (0.10). The slopes obtained for SPM obtained resulted positive using the three methods $(0.18$, 0.22 and 0.30 for M1, M2 and M3, respectively).

The coefficients of determination were very low in all the cases, with a maximum value of 0.12 for the correlation between direct and remote observations using method M1 for SPM. The RMSE (Table 2) exceeded the expected 35\% (HOOKER; MCCLAIN, 2000; EPLEE et al., 2001) for all the methods and for both variables. The PCC was
Table 1. Total in situ observations for each of the variables under study and number of pairs of field and satellite data obtained with each of the three methods of exclusion employed

\begin{tabular}{ccccc}
\hline \multicolumn{2}{c}{ Sample number } & \multicolumn{3}{c}{ Method } \\
\hline Variable & Field & M1 & M2 & M3 \\
Chlo-a & 151 & 10 & 11 & 13 \\
SPM & 100 & 20 & 26 & 29 \\
\hline
\end{tabular}

very low, less than 0.33 in all the cases, indicating a poor performance of the MODIS data set processed with the OC5 algorithm.

\section{DISCUSSION}

Results presented in the previous section reveal that MODIS data processed with the OC5 algorithm have a low correlation with in situ observations collected at the estuarine region of the RDP. This poor performance might be related to a number of factors such as: (I) the empirical nature of the algorithm; (II) the amount and distribution of the data used; (III) the composition of the phytoplankton in the region; (IV) the presence of other optically active substances in the water; (V) failures in the atmospheric corrections to the data, and/or (VI) the spatial variability of the analyzed parameters.

OC5 is a regional empirical algorithm, which performed well in the $\mathrm{BB}$, driving to an $\mathrm{R}^{2}$ of 0.7 for Chlo-a (GOHIN et al., 2002) and of 0.6 for SPM (GOHIN et al., 2005) in that region. By contrast, our results for the RDP show very low values for the $\mathrm{R}^{2}$ and PCC coefficients, evidencing a low linear correlation between the in situ observations and the satellite data processed with the OC5 algorithm. These results support the hypothesis that empirical algorithms can be very sensitive to changes in water composition and would, therefore, only have validity at a regional level (FARGION; MUELLER, 2000; PÉREZ-MARRERO et al., 2002).

However, it is important to discuss other possible causes for the poor performance of the data processed with OC5. Firstly, the number of matching data pairs available for the validation discussed in this study was significantly lower than those used by GOHIN et al. $(2002 ; 2005)$ for the BB. Whereas those authors found 178 data pairs for Chlo-a (GOHIN et al., 2002) and 158 for SPM (GOHIN et al., 2005), we only found between 10 and 13 pairs for Chlo-a and between 20 and 29 for SPM, depending on the exclusion method used, for the RDP. It has been suggested that the validation of satellite data requires a large number 

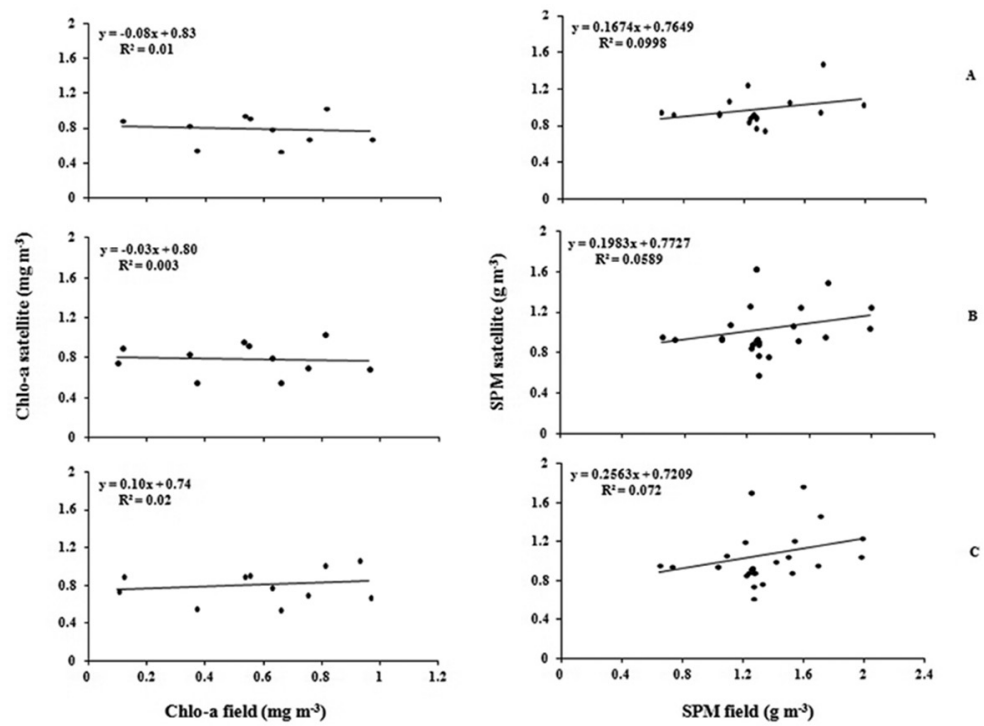

Figure 4. Scatter plot between in situ and remote observations of chlorophyll-a (left panel) and suspended particulate matter (right panel), obtained using the exclusion methods M1 (A), M2 (B) and M3 (C)

Table 2. Pearson correlation coefficient (PCC) and root mean square log error (RMSE) obtained for both variables studied with each of the three exclusion methods

\begin{tabular}{ccccc}
\hline \multicolumn{5}{c}{ Satelite window } \\
\hline Statiscal & M1 & M2 & M3 & Variable \\
PCC & 0.1 & -0.03 & 0.25 & Chlo-a \\
PCC & 0.33 & 0.26 & 0.27 & SPM \\
RMSE & $37.4 \%$ & $40.67 \%$ & $37.53 \%$ & Chlo-a \\
RMSE & $40.34 \%$ & $44.26 \%$ & $47.23 \%$ & SPM \\
\hline
\end{tabular}

of in situ observations (WERDELL; BAILEY, 2005) but this is obviously not the case in the RDP.

Moreover, the values of the concentration of Chlo-a found in this study, which varied between 1.25 and $9.16 \mathrm{mg} \mathrm{m}^{-3}$, are within the thresholds where the OC5 algorithm overestimates this parameter (GOHIN et al., 2002). The maximum values of SPM concentration in the RDP samples used in this study were about 40 times higher $\left(96.67 \mathrm{~g} \mathrm{~m}^{-3}\right)$ than the maximum values found for the BB $\left(2.50 \mathrm{~g} \mathrm{~m}^{-3}\right)$, whereas the minimum found for RDP (4.44 $\mathrm{g} \mathrm{m}^{-3}$ ) was double the minimum value found for the BB. The OC5 algorithm uses the additional band of 670 $\mathrm{nm}$ to recover the SPM concentration for concentrations above $4 \mathrm{~g} \mathrm{~m}^{-3}$, because the $555 \mathrm{~nm}$ band suffers much interference from these concentrations (GOHIN, 2011). However, the algorithm seems to remain inefficient for the RDP region even with the use of the extra band. MOREIRA et al. (2013) thus suggested that it would be possible to achieve a better estimation for the region and its adjacent waters using the reflectance in the long wavelength of $865 \mathrm{~nm}$.

The annual cycles of the phytoplanktonic communities in both the BB (VARELA, 1996) and the RDP (THORNTHWAITE, 1948) are typical of temperate seas. However, the specific composition and size of the phytoplankton are different. The BB is mainly inhabited by microplankton with sizes between 20 and $200 \mu \mathrm{m}$ throughout the year (FERNÁNDEZ; BODE, 1994). Although in the RDP region microplankton can also be found, nanoplankton $(2-20 \mu \mathrm{m})$ and picoplankton $(0.2-2 \mu \mathrm{m})$ predominate in the intermediate and outer regions of the estuary, respectively (CARRETO et al., 2007). This difference between the two systems might be one of the factors causing variations in the satellite observations, because the specific composition of phytoplankton can change the optical properties of the water (LUTZ et al., 2006) causing variations in marine radiance, regardless of changes in the concentration of pigments (SATHYENDRANATH et al., 2001). This can lead to erroneous estimates of the Chlo-a concentration (SATHYENDRANATH et al., 2001). Phytoplankton size can produce a decrease of the absorption coefficient per unit Chlo-a (LUTZ et al., 2006) due to the packaging effect (MOREL; BRECAUD, 1981). This effect theoretically predicts a decrease in the efficiency of absorption with the increase of the cell size and the intracellular concentration of pigments (SATHYENDRANATH et al., 1987), leading to an underestimation of the Chlo-a concentration when 
empirical algorithms are used. The presence of other optically active elements such as colored dissolved organic matter (CDOM or gelbstoff) and sediments can also lead to errors in the estimations of the concentration of Chlo-a (BRECAUD et al., 1983). CDOM is present in coastal regions defined as type 2 waters (CARDER et al., 1991) and particularly in the RDP estuary (ARMSTRONG et al., 2004). In addition, the inner and intermediate regions of the RDP contain large amounts of suspended sediments that scatter the light, creating the effect of bright pixel (GOHIN et al., 2002). It is noteworthy that GOHIN et al. (2002) also found it difficult to retrieve satellite values in areas close to the coast of $\mathrm{BB}$ using the $\mathrm{OC} 5$ algorithm.

It is known that the presence of aerosols influences the transfer of solar radiation through the atmosphere (SMICHOWSKI; GÓMEZ, 2012). For this reason, the proximity to large urban centers and the aerosols produced there could be an additional reason for the shortcomings found for the OC5 algorithm in the RDP. In particular, the inner and intermediate portions of the RDP are densely populated and industrialized, with very important harbor areas (DADON; MATTEUCCI, 2006). Thus the masks used to filter the effect of aerosols remove pixels mainly in those regions.

The MODIS observations have a spatial resolution of $1.1 \mathrm{~km}$ which, although it is appropriate to provide a synoptic view of the spatial-temporal variability of environmental variables (SIMIONATO et al., 2011a), may not be sufficient in coastal regions where the composition of the water can change dramatically on the horizontal plane over very short distances (BASTIDAS; RODRÍGUEZ-RUBIO, 2006). Thus it is possible that the $3 \times 3$ pixel box used in this study is too large relative to the spatial variability presented by the variables analyzed in the RDP. If this is the case, an average over an area of about $3 \times 3 \mathrm{~km}$, can likely underestimate or overestimate the concentration of the variables. However, the method of matching using the nearest neighbor did not lead to a good correlation between directly and remotely observed variables either. It is known that the SPM, especially those coming from fluvial sources, accumulates in the maximum turbidity zone, where the residence time is longer than it is upstream (HERMAN; HEIP, 1999). The amount of SPM also depends on many other factors, as for instance the tides, the variability in the runoff, the effect of the winds and waves, and the topography. Because of all those factors, the concentration of SPM can rapidly change and can have large spatial variability (GOHIN et al., 2005; MOREIRA et al., 2013). Perhaps in order to have a more realistic vision of this variable, smaller pixels would be needed. The temporal resolution might also be a problem, because the data could correspond to paired samples acquired at very different times of the day thus contributing to a reduction of the correlation.

With respect to the spatial variability of the Chlo-a concentration, in coastal areas the highest concentrations occur in the first 10 meters below the surface of the central and northern sectors of the RDP's mouth (CARRETO et al., 1986). This is where the matching pairs of data were located. Moreover, decreasing the concentration of the Chlo-a in estuarine regions is limited to a thin layer euphotic due to high turbidity which characterizes this region (CARRETO et al., 1986).This could be a reason why only a few pairs of data are found in other areas of the study region.

The results of this study, in short, reaffirm the need to develop regional algorithms that specifically consider the physical and biological characteristics of the region concerned. Future work in that direction is envisaged.

\section{ACKNOWLEDGEMENTS}

This study is a contribution to the ANPCyT project PICT 2010-1831 and contribution INIDEP 1960. Martina Camiolo's participation was made possible thanks to an ANPCyT Doctoral Fellowship within the scope of that project. The authors wish to acknowledge the value of the comments on and suggestions regarding the manuscript made by Dr. Andrés Jaureguizar, Lic. Lucrecia Allega and Dra. Eleonora Verón.

\section{REFERENCES}

ACHA, E. M.; MIANZAN, H.; LASTA, C. A.; GUERRERO, R.A. Estuarine spawning of the whitemouth croaker Micropogonias furnieri (Pisces: Sciaenidae), in the Río de la Plata, Argentina. Mar. Freshw. Res., v. 50, p. 57-65, 1999.

ACHA, E. M.; MIANZAN, H. W.; IRIBARNE, O.; GAGLIARDINI, D. A.; LASTA, C.; DALEO, P. The role of the Río de la Plata bottom salinity front in accumulating debris. Mar. Pollut. Bull., v. 46, n. 2, p. 197-202, 2003.

ACHA, E. M.; SIMIONATO, C. G.; CAROZZA, C.; MIANZAN, H. Climate-induced year-class fluctuations of whitemouth croaker Micropogonias furnieri (Pisces, Sciaenidae) in the Río de la Plata estuary, Argentina-Uruguay. Fish. Oceanog., v. 21, n. 1, p. 58-77, 2012.

AMERICAN PUBLIC HEALTH ASSOCIATION. Standard Methods for the Examination of Water and Wastewater. Washington: APHA/AWWA/WPCF, 1999. p. 2-56.

ARMSTRONG, R. A.; GILBES, F.; GUERRERO, R.; LASTA, C.; BENAVIDEZ, H.; MIANZAN, H. Validation of SeaWiFSderived chlorophyll for the Rio de la Plata Estuary and adjacent waters. Int. J. Remote Sens., v. 25, n. 7/8, p. 1501-1505, 2004. 
BAILEY, S. W.; WERDELL, P. J. A multi-sensor approach for the on-orbit validation of ocean color satellite data products. Remote Sens. Environ., v. 102, n. 1/2, p. 12-23, 2006.

BASTIDAS, M.; RODRIGUEZ-RUBIO, E. Validación de la concentración de clorofila a generada por el sensor modis-aqua con datos in situ el Pacífico Colombiano. Rev. Soc. Col. Fís., v. 38, n. 2, p. 774-777, 2006.

BRECAUD, A.; MOREL, A.; PRIEUR, L. Optical efficiency factors of some phytoplankters. Limnol. Oceanogr., v. 28, n. 5, p. 816-832, 1983.

BOSCHI, E. E. El ecosistema estuarial del Río de la Plata. (Argentina y Uruguay). An. Inst. Cienc. Mar. Limnol., v. 15, n. 2, p. 159-182, 1988.

CAMPBELL, J. W. The lognormal distribution as a model for biooptical variability in the sea. J. Geophys. Res., v. 100, n. 7, p. 13237-13254, 1995.

CARDER, K. L.; HAWES, K. S.; BAKER, K. A.; SMITH, R. C.; STEWARD, R. G.; MITCHELL, B. G. Reflectance model for quantifying chlorophyll a in the presence of productivity degradation products. J. Geophys. Res., v. 96, n. 11, p. 599-611, 1991.

CAROZZA, C. R.; HERNÁNDEZ, D. R.; PERROTTA, R. G. Evaluación de Corvina rubia (Micropogonias furnieri) en el área del Río de la Plata y Zona Común de Pesca Argentino-Uruguaya por medio de un modelo de dinámica de biomasa. Rev. Invest. Des. Pesq., v. 16, p. 77-90, 2004.

CARRETO, J. I.; NEGRI, R. M.; BENAVIDES, H. R. Algunas características del florecimiento del fitoplancton en el frente del Río de la Plata, I: Los sistemas nutritivos. Rev. Invest. Des. Pesq., INIDEP, Mar del Plata, v. 5, p. 7-29, 1986.

CARRETO, J. I.; CARIGNAN, M.; MONTOYA, N.; CUCCHI COLEONI, A. Ecología del fitoplancton en los sistemas frontales del mar Argentino. In: CARRETO, J. I.; BREMEC, C., eds. El mar Argentino y sus Recursos Pesqueros, v. 5, p. 11-31, 2007.

CARP (Comisión Administradora del Río de la Plata), 1989. Estudio para la evaluación de la contaminación en el Río de la Plata. Montevideo-Buenos Aires: Comisión Administradora del Río de la Plata. Informe de Avance, 1989. 422 p.

DADÓN, J. R.; MATTEUCCI, S. D. Caracterización de las grandes regiones costeras de la Argentina. In: ISLA, I.; LASTA, C. (Eds.). Manual de Manejo Costero para la Provincia de Buenos Aires. Mar del Plata: Universidad Nacional de Mar del Plata, 2006. $281 \mathrm{p}$.

DEPETRIS, P. J.; GRIFFIN, J. J. Suspended load in the Río de la Plata drainage basin. Sedimentology, v. 11, n. 1/2, p. 53-60, 1968.

DOGLIOTTI, A. I.; RUDDICK, K.; NECHAD, B.; LASTA, C.; MERCADO, A.; HOZBOR, C.; GUERRERO, R.; RIVIELLO LÓPEZ, G.; ABELANDO, M. Calibration and validation of an algorithm for remote sensing of turbidity over La Plata river estuary, Argentina. EARSeL eProceedings, v. 10, n. 2, p. 119130, 2011.

EPLEE, R. E.; ROBINSON, W. D.; BAILEY, S. W.; CLARK, D. K.; WERDELL, P. J.; WANG, M.; BARNES, R. A.; MCCLAIN, C. R. Calibration of SeaWiFS. II. Vicarious techniques. Appl. Opt., v. 40, n. 36, p. 6701-6718, 2001.

FARGION, G. S.; MUELLER, J. L. Ocean Optics Protocols for Satellite Ocean Color Sensor Validation. Revision 2. Greenbelt: NASA/TM-2000-209966, 2000. p. 189.
FERNÁNDEZ, E.; BODE, A. Succession of phytoplankton assemblages in relation to the hydrography in the southern Bay of Biscay: A multivariate approach. Sci. Mar., v. 58, n. 3, p. 191-205, 1994.

FRAMIÑAN, M. B.; BROWN, O. B. Study of the Río de la Plata turbidity front, Part I: Spatial and temporal distribution. Cont. Shelf Res., v. 16, n. 10, p. 1259-1282, 1996.

GOHIN, F.; DRUON, J. N.; LAMPERT, L. A five channel chlorophyll concentration algorithm applied to SeaWIFS data processed by SeaDAS in coastal waters. Int. J. Remote Sens., v. 23, n. 8, p. 1639-1661, 2002.

GOHIN, F.; LOYER, S.; LUNVEN, M.; LABRY, C.; FROIDEFOND, J. M.; DELMAS, D.; HURET, M; HERBLAND, A. Satellite-derived parameters for biological modelling in coastal waters: illustration over the eastern continental shelf of the Bay Biscay. Remote Sens. Environ., v. 95, n. 1, p. 29-46, 2005.

GOHIN, F. Annual cycles of chlorophyll-a, non-algal suspended particulate matter, and turbidity observed from space and insitu in coastal waters. Ocean Sci., v. 7, n. 1, p. 705-732, 2011.

GUERRERO, R. A.; ACHA, M. E.; FRAMIÑAN, M. B.; LASTA, C. A. Physical oceanography of the Río de la Plata Estuary, Argentina. Cont. Shelf Res., v. 17, n. 7, p. 727-742, 1997.

HERMAN, P. M. J.; HEIP, C. H. R. Biogeochemistry of the MAximum TURbidity zone of Estuaries (MATURE): Some conclusions. J. Mar. Syst., v. 22, n. 2/3, p. 89-104, 1999.

HOOKER, S. B.; MCCLAIN, C. R. The calibration and validation of SeaWiFS data. Prog. Oceanogr., v. 45, n. 3/4, p. 427-465, 2000.

INSTITUTO NACIONAL DEL AGUA (INA). Generación y transporte de sedimentos en la Cuenca Binacional del Río Bermejo. Caracterización y análisis de los procesos intervinientes. Buenos Aires: COBINABE, 2010. $230 \mathrm{p}$.

JAUREGUIZAR, A. J.; MENNI, R. C.; BREMEC, C. S.; MIANZAN, H. W.; LASTA, C. A. Fish assemblage and environmental patterns in the Río de la Plata estuary. Estuar. Coast. Shelf Sci., v. 56, n. 5/6, p. 921-933, 2003a.

JAUREGUIZAR, A. J.; MILITELLI, M. I.; GUERRERO, R. Distribution of Micropogonias furnieri at different maturity stages along an estuarine gradient and in relation to environmental factors. J. Mar. Biol. Assoc. U. K., v. 88, n. 1, p. 175-181, 2008.

JEFFREY, S. W.; HUMPHREY, G. F. New spectrophotometric equations for determining chlorophylls $\mathrm{a}, \mathrm{b}, \mathrm{c} 1$ and $\mathrm{c} 2$ in higher plants, algae and natural phytoplankton. Biochem. Physiol. Pfl., v. 167, p. 191-194, 1975.

LASTA, C. A.; RUARTE, C. O.; CAROZZA, C. R. Flota costera Argentina: antecedentes y situación actual. In: BERTOLOTTI, M. I.; VERAZAY, G. A.; AKSELMAN, R. (Eds.). El mar Argentino y sus Recursos Pesqueros. Mar del Plata. Argentina: INIDEP Publicaciones Especiales, 2001. p. 89-106.

LÓPEZ LABORDE, J.; NAGY, G. Hydrography and sediment transport characteristics of the Río de la Plata: a review. In: PERILLO, G. M. E.; PICCOLO, M. C.; PINO, M. (Eds.) Estuaries of South America: Their geomorphology and dynamics. Hydrography and Sediment Transport Characteristics of the Rio de la Plata. Berlin: Springer; 1999. p. 133-160.

LUTZ, V. A.; SUBRAMANIAM, A.; NEGRI, R. M.; SILVA, R. I.; CARRETO, J. I. Annual variations in bio-optical properties at the 'Estación Permanente de Estudios Ambientales (EPEA)' coastal station, Argentina. Cont. Shelf Res., v. 26, n. 10, p. 1093-1112, 2006. 
LUZ CLARA, M.; SIMIONATO, C. G.; D’ONOFRIO, E.; FIORE, M.; MOREIRA, D. Variability of tidal constants in the Río de la Plata Estuary associated to the natural cycles of the runoff. Est. Coast. Shelf Sci., v. 148, n. 5, p. 85-96, 2014.

MACCHI, G. J.; CHRISTIANSEN, H. E. Análisis temporal del proceso de maduración y determinación de la incidencia de atresias en la corvina rubia, (Micropogonias furnieri). Frente Marít., v. 16, p. 93-10, 1996.

MACCHI, G. J.; ACHA, E. M. Aspectos reproductivos de las principales especies de peces de la zona común de pesca Argentino-Uruguaya y en el Rincón. Noviembre 1994. INIDEP Inf. Téc. Oficial, v. 21, p. 67-89, 1998.

MCCLAIN, C.; HOOKER, S.; ESAIAS, W.; FELDMAN, G.; FROUIN, R.; GREGG, W., FROUIN, R. The Proposal for the NASA Sensor Intercalibration and Merger for Biological and Interdisciplinary Oceanic Studies (SIMBIOS) Program, 1995. Greenbelt: NASA Goddard Space Flight Center; 2002.

MECCIA, V. L.; SIMIONATO, C. G.; FIORE, M. M. E.; D'ONOFRIO, E. E.; DRAGANI, W. C. Sea surface height variability in the Río de la Plata estuary from synoptic to interannual scales: results of numerical simulations. Estuar. Coast. Shelf Sci., v. 85, n. 2, p. 327-343, 2009.

MECCIA, V. L.; SIMIONATO, C. G.; GUERRERO, R. The Río de la Plata estuary response to wind variability in synoptic time scale: salinity fields and breakdown and reconstruction of the salt wedge structure. J. Coastal Res., v. 29, n. 1, p. 61-77, 2013.

MIANZÁN, H. W.; LASTA, C. A.; ACHA, E. M.; GUERRERO, R. A.; MACCHI, G. J.; BREMEC, C. The Río de la Plata estuary, Argentina-Uruguay. In: SEELIGER, U.; KJERFVE, B. (Eds.). Coastal Marine Ecosystems of Latin America. Ecological Studies. Berlin: Springer, 2000. p. 185-204.

MOREIRA, D.; SIMIONATO, C. G.; GOHIN, F.; CAYOCCA, F.; TEJEDOR, M. L. C. Suspended matter mean distribution and seasonal cycle in the Río de la Plata estuary and the adjacent from ocean color satellite (MODIS) and in situ observations. Cont. Shelf Res., v. 68, p. 51-66, 2013.

MOREL, A.; PRIEUR, L. Analysis of variations in ocean colour. Limnol. Oceanogr., v. 22, p. 709-722, 1977.

MOREL, A.; BRECAUD, A. Theoretical results concerning light absorption in a discrete medium and application to specific absorption of phytoplankton. Deep-Sea Res., v. 28, n. 11, p. 1375-1393, 1981

OLSEN, S.; PADMA, T.; RICHTER, B. Guía para el manejo del flujo de agua dulce a los estuarios. Washington, Kingston: Usaid, The Nature Conservancy y Coastal Resources Center (CRC), 2007. 52 p.

PATT, F. S. 2002. Navigation algorithms for the seaWIFS mission. NASA Tech. Memo. vol. 206892. Greenbelt, MD: National Aeronautics and Space Administration, Goddard Space Flight Center.

PÉREZ-MARRERO, J.; MAROTO, L.; GODOY, J.; VILLAGARCÍA, M.; CIANCA, A.; RUEDA, M. J.; LLINÁS, O. Validación de modelos para la determinación de clorofila "a" a partir de imágenes SeaWIFS en el atlántico centro-oriental. Rev. Teledetección, v. 17, p. 55-60, 2002.

PIZARRO, M. J.; ORLANDO, A. M. Distribución de fósforo, nitrógeno y silicio disuelto en el Río de la Plata. Serv. Hidr. Naval. Secr. Mar. Publ. H., v. 625, p. 1-57, 1984.

PUIG, P.; GRÜNWALDT, P.; GONZÁLEZ, S. Pesquería artesanal de corvina en Uruguay. Frente Marít., v. 21, p. 23-35, 2010.
QUISPE, D.; CALIENES, R.; TAM, J.; GRACO, M.; LEDESMA, J.; FLORES, G.; CORREA, D.; QUISPE, C. Análisis comparativo entre clorofila-a satelital e in situ en el ecosistema de afloramiento Peruano, entre 1998-2007. Ecol. Appl., v. 9, n. 2, p. 151-159, 2010.

ROBERTSON, A. W.; MECHOSO, C. R. Interannual and decadal cycles in river flows of southeastern South America. J. Clim., v. 11, p. 2570-2581, 1998.

SATHYENDRANATH, S.; LAZZARA, L. C.; PRIEUR, L. Variations in the spectral values of specific absorption of phytoplankton. Limnol. Oceanogr., v. 32, n. 2, p. 403-415, 1987.

SATHYENDRANATH, S.; COTA, G.; STUART, V.; MAASS, H.; PLATT, T. Remote sensing of phytoplankton pigments: a comparison of empirical and theoretical approaches. Int. J. Remote Sens., v. 22, n. 2/3, p. 249-273, 2001.

SIMIONATO, C. G.; DRAGANI, W. C.; MECCIA, V. L.; NUNEZ, M. N. A numerical study of the barotropic circulation of the Río de la Plata Estuary: sensitivity to bathymetry, Earth rotation and low frequency wind variability. Estuar. Coast. Shelf Sci., v. 61, n. 2, p. 261-273, 2004.

SIMIONATO, C. G.; VERA, C. S.; SIEGISMUND, F. Surface wind variability on seasonal and interannual scales over Río de la Plata area. J. Coastal. Res., v. 21, n. 4, p. 770-783, 2005a.

SIMIONATO, C. G.; MECCIA, V. L.; DRAGANI, W. C.; NUNEZZ, M. N. Barotropic tide and baroclinic waves observations in the Río de la Plata Estuary. J. Geophys. Res. Atmos., v. 110, n. 6, 2005b.

SIMIONATO, C. G.; MECCIA, V. L.; DRAGANI, W. C.; GUERRERO, R.; NUÑEZ, M. N. The Río de la Plata estuary response to wind variability in synoptic to intraseasonal scales: barotropic response. J. Geophys. Res., v. 111, n. 9, 2006b.

SIMIONATO, C. G.; MECCIA, V. L.; GUERRERO, R. A.; DRAGANI, W. C.; NUÑEZ, M. N. Río de la Plata estuary response to wind variability in synoptic to intraseasonal scales: 2 . Currents' vertical structure and its implications for the salt wedge structure. J. Geophys. Res., v. 112, n. 7, 2007.

SIMIONATO, C. G.; BERASATEGUI, A.; MECCIA, V. L.; ACHA, M.; MIANZÁN, H. Short time-scale wind forced variability in the Río de la Plata estuary and its role on ichthyoplankton retention. Estuar. Coast. Shelf Sci., v. 76, n. 2, p. 211-226, 2008.

SIMIONATO, C. G.; MOREIRA, D.; PIEDRA-CUEVA, I; FOSSATI, M.; GUERRERO, R. A.; DE LOS CAMPOS, T.; BALESTRINI, C.; CAYOCCA, F.; GOHIN, F.; REPECAUD, M. Proyecto FREPLATA-FFEM modelado numérico y mediciones in situ y remotas de las transferencias de sedimentos finos a través del Río de la Plata Parte A: Adquisición de datos. Frente Marít., v. 22, p. 237-264, 2011a.

SIMIONATO, C. G.; MOREIRA, D.; RE, M; FOSSATI, M. Estudio de la dinámica hidro-sedimentológica del Río de la Plata: observación y modelación numérica de los sedimentos finos. Frente Marít., v. 22, p. 265-304, 2011b.

SMICHOWSKI, P.; GÓMEZ, D. R., Atmospheric Aerosols, Analysis of Atomic Spectroscopy. In: MEYERS, R. A. (ed). Encyclopedia of Analytical Chemistry. Applications, Theory and Instrumentation.Chichester: John Wiley and Sons; 2012.

SYKES, P. A.; BARCIELA, R. M. Assessment and development of a sediment model within an operational system. J. Geophys. Res., v. 117, n. c4, 2012. 
THORNTHWAITE, C. W. An approach toward a rational classification of climate. Geogr. Rev., v. 38, p. 55-94, 1948.

URIEN, C. M. Los sedimentos modernos del Río de la Plata Exterior. Serv. Hidrogr. Naval, v. 4, n. 2, p. 113-213, 1967.

VARELA, M. Phytoplankton ecology in the Bay of Biscay. Sci. Mar., v. 60, n. Supl. 2, p. 45-53, 1996.
WERDELL, P. J; BAILEY, S. W. An improved in-situ bio-optical data set for ocean color algorithm development and satellite data product validation. Remote Sens. Environ., v. 98, p. 122-140, 2005.

WILSON, C.; MORALES, J.; SHAILESH, N.; ASANUMA, I.; FELDMAN, G. Ocean-colour radiometry and fisheries. In: PLATT, T.; HOEPFFNER, N.; STUART, V.; BROWN, C. (Eds.) Why ocean colour? The societal benefits of ocean-colour technology. Report n 7. Dartmouth: IOCCG; 2008, 141 p. 